\title{
PENGARUH AROMATERAPI MINYAK ATSIRI MAWAR TERHADAP INTENSITAS NYERI PERSALINAN KALA 1 FASE AKTIF DI PUSKESMAS PANGALENGAN KABUPATEN BANDUNG
}

\author{
*Keke Susilowati Sholehah ${ }^{1)}$, Lisa Trina Arlym ${ }^{2)}$, Ashar Nuzulul Putra ${ }^{3)}$ \\ ${ }^{1-2)}$ Program Studi D-IV Bidan Pendidik, STIKes Mitra RIA Husada \\ 3) Program Studi S1 Kesehatan Masyarakat, STIKes Mitra RIA Husada \\ Correspondence author: ksusilowatisholehah@gmail.com, Jakarta, Indonesia
}

DOI: https://doi.org/10.37012/jik.v12i1.116

\begin{abstract}
ABSTRAK
Nyeri persalinan disebabkan oleh kontraksi miometrium, regangan segmen bawah rahim dan serviks, serta iskemia otot rahim sebagai proses fisiologis yang menimbulkan rasa takut dan khawatir yang dapat berdampak pada ibu dan janin. Seperti yang diketahui aromaterapi minyak atsiri bunga mawar adalah salah satu metode nonfarmakologis untuk menangani nyeri dengan mengeluarkan neuromodulator yaitu endorphin dan enkafalin yang berfungsi sebagai penghilang rasa sakit alami dan menghasilkan perasaan tenang. Penelitian ini adalah penelitian preeksperimental dengan memberikan intervensi aromaterapi minyak atsiri bunga mawar pada 44 orang ibu primigravida dan multigravida saat persalinan kala 1 fase aktif. Penilaian intensitas nyeri persalinan menggunakan instrumen Numeric Rating Scale dan Wong Baker Faces Pain Rating Scale sebelum dan sesudah pemberian aromaterapi. Terdapat pengaruh aromaterapi minyak atsiri bunga mawar terhadap penurunan intensitas nyeri persalinan kala 1 fase aktif. Berdasarkan hasil penelitian, direkomendasikan agar aromaterapi minyak atsiri bunga mawar dapat digunakan sebagai terapi komplementer kepada ibu bersalin kala I fase aktif.
\end{abstract}

Kata kunci: Aromaterapi, Kala I Fase Aktif, Minyak Atsiri Bunga Mawar, Nyeri Persalinan.

\begin{abstract}
Labor pain is due to myometrial contractions, the stretch of the lower uterine and cervical segments, and uterine muscle ischemia as a physiological process that causes fear and worry that can affect the mother and fetus. Essential oils of roses aromatherapy are one of the nonpharmacological methods for dealing pain by releasing neuromodulators which is endorphins and encafaline that act as natural pain relievers and produce a relaxing feeling. The study was pre-experimental by given essential oil of roses aromatherapy to mothers of primigravida and multigravida on the first active phase of labor. Assessment of labor pain intensity using Numeric Rating Scale and Wong Baker Faces Pain Rating Scale instruments when pre-test and post-test given aromatherapy. There is an effect of essential oils of roses aromatherapy to decrease the intensity of labor pain on the first active phase of labor. Based on the results of the study, it is recommended that essential oil of roses aromatherapy can be used as a complementary therapy to mothers during the first active phase of labor.
\end{abstract}

Key words: Aromatherapy, Essential Oils Of Roses, First Active Phase, Labor Pain. 


\section{PENDAHULUAN}

Persalinan adalah proses dimana bayi, plasenta, dan selaput ketuban keluar dari uterus ibu. Persalinan dimulai (inpartu) sejak uterus berkontraksi dan menyebabkan perubahan pada serviks (membuka dan menipis). (Kemenkes RI, 2008). Secara umum persalinan dianggap sebagai peristiwa yang menggembirakan, namun rasa gembira itu dapat berubah menjadi suatu keputusasaan ketika seorang ibu merasakan nyeri persalinan dan meragukan kemampuannya untuk menyelesaikan persalinannya dengan baik ketika kontraksinya menjadi lebih intens. (Mander R, 2004).

Secara umum nyeri adalah suatu rasa yang tidak nyaman, baik ringan maupun berat. Nyeri didefinisikan sebagai suatu keadaan yang mempengaruhi seseorang dan eksistensinya diketahui bila seseorang pernah mengalaminya. (Tamsuri, 2007). Disamping itu, menurut International Association of the Study of Pain (2015). Nyeri adalah pengalaman perasaan emosional yang tidak menyenangkan akibat terjadinya kerusakan aktual maupun potensial, atau menggambarkan kondisi terjadinya kerusakan. Pendapat lain juga menyatakan nyeri adalah pengalaman sensori dan emosional yang tidak menyenangkan akibat dari kerusakan jaringan yang aktual dan potensial. Sehingga nyeri adalah sensasi yang tidak menyenangkan dan sangat individual yang tidak dapat di ungkapkan kepada orang lain. (Ratiningsih, 2010)

Nyeri persalinan disebabkan adanya regangan segmen bawah rahim. (Farer H, 2001) Intensitas nyeri sebanding dengan kekuatan kontraksi dan tekanan yang terjadi, nyeri bertambah ketika mulut rahim dalam dilatasi penuh akibat tekanan bayi terhadap struktur panggul diikuti regangan dan perobekan jalan lahir. Nyeri persalinan unik dan berbeda pada setiap individu karena nyeri tidak hanya dikaitkan dengan kondisi fisik semata, tetapi berkaitan juga dengan kondisi psikologis ibu pada saat persalinan.

Nyeri persalinan dapat menimbulkan stres yang menyebabkan pelepasan hormon yang berlebihan seperti katekolamin dan steroid. Hormon ini dapat menyebabkan terjadinya ketegangan otot polos dan vasokontriksi pembuluh darah. Menurut Sumarah (2009) hal ini dapat menurunkan kontraksi uterus, pengurangan aliran darah dan oksigen ke uterus serta timbulnya iskemia uterus yang membuat implus nyeri bertambah banyak. Nyeri persalinan juga dapat menyebabkan hiperventilasi sehingga kebutuhan oksigen meningkat, naiknya tekanan darah, berkurangnya motilitas usus dan vesika urinari. 
Keadaan ini dapat merangsang kenaikan katekolamin yang dapat menyebabkan gangguan pada kekuatan kontraksi uterus sehingga terjadi inersia uterus yang dapat mengakibatkan kematian ibu saat melahirkan. (Llewllyn D, 2001).

Persalinan berhubungan dengan dua jenis nyeri yang berbeda. Pertama nyeri berasal dari otot rahim, pada saat otot ini berkontraksi nyeri yang timbul disebut nyeri viseral. Nyeri ini tidak dapat ditentukan dengan tepat lokasinya (Pain-Pointed). Nyeri viseral juga dapat dirasakan pada orang lain yang bukan merupakan asalnya disebut nyeri alih (Reffered pain). Pada persalinan nyeri alih dapat diraasakan pada orang yitu punggung bagian bawah dan sacrum. Sedangkan nyeri yang kedua timbul pada saat mendekati kelahiran. Tidak seperti nyeri viseral, nyeri ini terlokalisir didaerah vagina, rectum dan perinium sekitar anus. Nyeri jenis ini disebut nyeri somatik dan disebabkan peregangan stuktur jalan lahir bagian bawah akibat penurunan bagian terbawah janin. (Bare B \& Smeltzer S, 2001).

Respon fisiologi terhadap nyeri berupa peningkatan tekanan darah, denyut nadi, pernafasan, keringat, dan ketegangan otot. Saat terjadi nyeri, pelepasan hormon stress akan meningkat, hormon stress tersebut menyebabkan terjadinya ketegangan otot polos dan vasokontriksi pembuluh darah sehingga terjadi penurunan kontraksi uterus selama kala I persalinan, penurunan sirkulasi uteroplasenta, hipoksia janin, serta pembukaan mulut rahim tidak adekuat sehingga waktu persalinan dapat bertambah lama. (Mender R, 2004).

Apabila nyeri persalinan ini dapat diatasi dengan baik, maka hormon stress dalam darah akan turun. Peranan petugas kesehatan adalah memberikan bantuan dan dukungan pada ibu berupa manajemen pengurangan nyeri agar seluruh rangkaian proses persalinan berlangsung aman dan nyaman baik bagi ibu maupun bagi bayi yang dilahirkan (Utami R. \& Nurul M., 2013). Didalam Peraturan Pemerintah RI tentang Pelayanan Kesehatan Tradisional (2014) menyatakan bahwa salah satu cara menurunkan angka kesakitan adalah dengan memberikan Pelayanan Kesehatan Tradisional Komplementer salah satunya dengan menggunakan ramuan yang berasal dari tanaman dana tau sediaan sarian. Pelayanan Kesehatan Komplementer dapat dijadikan metode yang dapat menjadi bagian dari perawatan medis. (Tournaire M. \& Theau-yonneau A., 2007). 
Kata aromaterapi berarti terapi dengan memakai minyak esensial yang ekstrak dan unsur kimianya diambil dengan utuh. Aromaterapi adalah bagian dari ilmu herbal (herbalism). (Poerwadi R., 2006) Sedangkan menurut Sharma S. (2009) aromaterapi berarti 'pengobatan menggunakan wangi-wangian'. Istilah ini merujuk pada penggunaan minyak esensial dalam penyembuhan holistik untuk memperbaiki kesehatan dan kenyamanan emosional dan dalam mengembalikan keseimbangan badan.

Terapi komplementer (pelengkap), seperti homoeopati, aromaterapi dan akupuntur harus dilakukan seiring dengan pengobatan konvensional. (Jones \& Nelson R., 2006).

Hasil penelitian pada 21 orang ibu bersalin membuktikan bahwa ada pengaruh pemberian aromaterapi lavender terhadap penurunan intensitas nyeri peralinan. Pemberian aromaterapi pada ibu bersalin mampu mengeluarkan neuromodulator yaitu endorphin dan enkafalin yang berfungsi sebagai penghilang rasa sakit alami dan menghasilkan perasaan tenang sehingga dapat mempengaruhi intensitas nyeri persalinan (Turlina L \& Fadhilah N, 2017). Penelitian lain juga menyimpulkan bahwa ada pengaruh latihan teknik pernafasan menggunakan aromaterapi lavender terhadap intensitas skala nyeri dan berkurangnya nyeri pada ibu post section caesarea (Pratiwi, dkk. 2012). Senada dengan pernyataan tersebut penelitian Utami R. \& Nurul M. (2013) telah membuktikan bahwa metode paling efektif untuk mengurangi intensitas nyeri kala I fase aktif persalinan normal primigravida adalah dengan memberikan dua puluh menit aromaterapi rose effleurage. Banyak minyak esensial yang memiliki sifat ini hingga derajat tertentu dan mengapa terjadi hal demikian tampaknya tidak ada keterangan yang dapat menjelaskan, mengingat rasa nyeri itu sendiri merupakan masalah yang rumit. Sifat analgesik ini diperkirakan terjadi sebagian akibat efek antiinflamasi, sirkulasi serta detoksifikasi yang ditimbulkan oleh beberapa jenis minyak esensial lainnya. Senyawa fenol eugenol yang ditemukan dalam minyak cangkih sudah kita kenal dengan baik sebagai obat sakit gigi, minyak winter green (yang mengandung metil salisilat, yaitu suatu senyawa ester) secara tradisional sudah dipakai sebagai obat gosok untuk menghilangkan pegal-pegal pada otot, dan menthol secara khusus sudah digunakan untuk nyeri kepala. (Price S \& Price L, 1997).

Bunga mawar berkhasiat sebagai cell rejuvenator yang membuat sel muda kembali, antiseptic, dan anti radang sehingga sering di gunakan dalam krim dan lotion untuk memperbaiki kondisi kulit. Baunya merupakan anti depresan, sedative dan meringankan 
stress. Minyak atsiri bunga mawar yang digunakan melalui inhalasi dapat bermanfaat meningkatkan kewaspadaan, meningkatkan daya ingat, meningkatkan kecepatan dalam berhitung serta melegakan otot dan pikiran. (Koensoemardiyah, 2009) Sujiyatini (2011) juga menegaskan bahwa bunga mawar bersifat anti depresan sehinggan dapat membuat jiwa menjadi tenang. Balkam (2001) memaparkan bahwa aromaterapi yang tepat dan menenangkan dapat mengurangi rasa sakit persalinan. Jenis aromaterapi yang aman digunakan untuk kehamilan dan persalinan antara lain rose, jasmine, lemon, lavender, dan pine.

Rasa senang menyambut kelahiran bayi dapat mendadak berubah menjadi sesuatu yang menakutkan ketika sang ibu membayangkan dan merasakan betapa hebat rasa sakit saat melahirkan. Berdasarkan studi pendahuluan terhadap 10 ibu nifas di Kecamatan Pangalengan terdapat $80 \%$ ibu yang merasakan nyeri berat saat persalinannya. Maka dari itu, penulis tertarik untuk melakukan penelitian tentang pengaruh aromaterapi minyak atsiri bunga mawar terhadap intensitas nyeri persalinan kala I fase aktif di Puskesmas Pangalengan Kabupaten Bandung.

\section{METODE}

Desain yang digunakan dalam penelitian ini adalah pre-eksperimental dan menggunakan one group pre-test post-test yaitu sampel pada penelitian ini diobservasi terlebih dahulu sebelum diberi perlakuan, kemudian diobservasi kembali setelah diberi perlakuan. (Notoatmodjo S., 2005) Penelitian ini dilakukan di Puskesmas Pangalengan Kabupaten Bandung. Pengambilan sampel dilakukan menggunakan teknik accidental sampling yaitu peneliti memilih responden berdasarkan adanya responden yaitu ibu inpartu yang datang ke Puskesmas pada bulan April - Mei yang sesuai dengan kriteria inklusi dan eksklusi yang telah ditetapkan peneliti dan didapatkan sejumlah 44 responden. Kriteria inklusi pada penelitian ini yaitu ibu yang bersedia menjadi responden penelitian, inpartu fase aktif pembukaan 4-10 cm, ibu bersalin pertama atau kedua kali, tidak sedang meminum obat analgesic dan tidak dilakukan tindakan lain untuk mengurangi rasa nyeri persalinan. Kriteria ekslusi pada penelitian ini adalah ibu yang mempunyai komplikasi. Pengambilan data intensitas nyeri dengan menggunakan Numeric Rating Scale dan Wong Baker Faces Pain Rating Scale. Pre-test dilakukan saat ibu bersalin mengalami pembukaan $4 \mathrm{~cm}$. 
Aromaterapi minyak atsiri bunga mawar diberikan kepada ibu selama 30 menit setelah itu responden dilakukan post-test.

Analisis yang digunakan dalam penelitian ini adalah menggunakan menggunakan uji Wilcoxon karena data berdistribusi tidak normal. Analisis korelasi dimaksudkan untuk melihat hubungan dari dua hasil pengukuran atau dua variable yang diteliti, untuk mengetahui derajat hubungan antara variable $\mathrm{X}$ (aromaterapi) dengan variable $\mathrm{Y}$ (intensitas nyeri). (Notoatmodjo, 2005) Pada penelitian ini menggunakan teknis korelasi tata jenjang atau rank correlation atau sering juga disebut uji korelasi Spearman Rank karena data dari instrument penelitian menggunakan skala numerik yang hasilnya berupa data ordinal atau berjenjang.

Aromaterapi yang digunakan adalah aromaterapi yang aman digunakan ibu hamil terdaftar dan memiliki izin edar dari Kementerian Kesehatan Republik Indonesia dengan nomor Perbekalan Kesehatan Dalam Negeri (PKD) 20601210219. Minyak atsiri bunga mawar sebanyak 4 tetes dituangkan dalam tungku aromaterapi yang telah diberi air sebanyak $10 \mathrm{cc}$ terlebih dahulu dan dihubungkan dengan listrik sehingga keramik tempat minyak atsiri bunga mawar dituangkan akan panas dan menguapkan wangi mawar.

\section{HASIL DAN PEMBAHASAN}

Penelitian ini dilakukan dengan beberapa keterbatasan penelitian yang dengan keterbatasan tersebut dapat berpengaruh terhadap hasil penelitian. Keterbatasanketerbatasan yang ada dalam penelitian ini adalah responden merupakan ibu primigravida dan multigravida, masih belum spesifik sehingga persepsi nyeri belum terlalu seragam, tidak mengumpulkan variable lain yang memungkinkan berakibat penurunan intensitas nyeri persalinan kala 1 fase aktif, bahan minyak atsiri bunga mawar yang digunakan peneliti bukan merupakan bahan terbaik, tidak melihat faktor besarnya pembukaan ibu bersalin.

Sebagian besar atau $84 \%$ ibu bersalin berumur 20-35 tahun dan sebagian kecil atau 1\% ibu bersalin umur > 35 tahun. Distribusi responden berdasarkan Pendidikan menunjukkan setengah atau $50 \%$ ibu bersalin berpendidikan SMP dan sebagian kecil atau $23 \%$ ibu bersalin berpendidikan SD. Distribusi responden berdasarkan pekerjaan menunjukkan sebagian besar atau $66 \%$ ibu bersalin sebagai ibu rumah tangga dan hanya sebagian kecil 
atau 2\% ibu bersalin bekerja sebagai Wirausaha. Distribusi responden berdasarkan paritas bahwa sebagian besar atau $75 \%$ ibu bersalin pada hamil kedua atau multigravida.

Tabel 1. Distribusi Frekuensi Karakteristik Ibu Bersalin $(n=44)$

\begin{tabular}{lcc}
\hline \multicolumn{1}{c}{ Karakteristik } & Frekuensi & Persentase (\%) \\
\hline Usia & 6 & 13,63 \\
$<20$ tahun & 37 & 84,09 \\
$20-35$ tahun & 1 & 2,27 \\
$>35$ tahun & & \\
\hline Pendidikan & 10 & 22,72 \\
SD & 22 & 50,00 \\
SMP & 12 & 27,27 \\
SMA & & \\
\hline Pekerjaan & 29 & 65,90 \\
IRT & 9 & 20,45 \\
Buruh & 5 & 11,36 \\
Wiraswasta & 1 & 2,27 \\
Wirausaha & & \\
\hline Paritas & 11 & 25,00 \\
Primigravida & 33 & 75,00 \\
Multigravida & & \\
\hline
\end{tabular}

Sumber: Data primer, 2018

Untuk menganalisis pengaruh aromaterapi minyak atsiri bunga mawar terhadap intensitas nyeri persalinan kala I fase aktif di Puskesmas Pangalengan Kabupaten Bandung Tahun 2018 dilakukan uji statistik wilcoxon Sign Rank Test. Dari tabel 5.4 di atas diketahui ratarata skala nyeri persalinan berdasarkan Numeric Rating Scale (NRS) sebelum intervensi adalah 5,43 dengan standar deviasi 1,52. Setelah dilakukan intervensi pemberian aromaterapi minyak atsiri bunga mawar rata-rata skala nyeri persalinan menjadi 4,50 dengan standar deviasi 1,85. Terlihat nilai rata-rata perbedaan antara sebelum dan sesudah intervensi adalah 0,93 dengan standar deviasi 0,33. Hasil uji statistic didapatkan nilai $\mathrm{P}$ 0,0001 hal ini berarti menunjukkan nilai $\mathrm{p}<0,05$ yang artinya maka dapat disimpulkan berdasarkan instrument skala nyeri Numeric Rating Scale (NRS) terdapat pengaruh aromaterapi minyak atsiri bunga mawar terhadap penurunan intensitas nyeri persalinan kala I fase aktif. 
Tabel 2. Distribusi Nilai Rata-Rata Skala Nyeri Persalinan Antara Sebelum dengan Sesudah Diberikan Aromaterapi Minyak Atsiri Bunga Mawar di Puskesmas Pangalengan Tahun 2018

\begin{tabular}{|c|c|c|c|c|c|}
\hline Variabel & $\mathbf{n}$ & Mean & SD & $\mathbf{S E}$ & P Value \\
\hline \multicolumn{6}{|l|}{$\begin{array}{l}\text { Skala Nyeri Persalinan berdasarkan Numeric } \\
\text { Rating Scale (NRS) }\end{array}$} \\
\hline - $\quad$ Sebelum Intervensi & 44 & 5,43 & $\begin{array}{c}1,5 \\
2\end{array}$ & 0,23 & 0.0001 \\
\hline - $\quad$ Setelah Intervensi & 44 & 4,50 & $\begin{array}{c}1,8 \\
5\end{array}$ & 0,28 & \\
\hline \multicolumn{6}{|l|}{$\begin{array}{l}\text { Skala Nyeri Persalinan berdasarkan Wong } \\
\text { Baker Faces Pain Rating Scale (WBS) }\end{array}$} \\
\hline - $\quad$ Sebelum Intervensi & 44 & 4,77 & $\begin{array}{c}1,9 \\
4\end{array}$ & 0,29 & 0,02 \\
\hline - $\quad$ Setelah Intervensi & 44 & 3,91 & $\begin{array}{c}2,3 \\
2\end{array}$ & 0,35 & \\
\hline
\end{tabular}

* Uji Wilcoxon

Selain itu, diketahui rata-rata skala nyeri persalinan berdasarkan Wong Baker Faces Pain Rating Scale (WBS) sebelum intervensi adalah 4,77 dengan standar deviasi 1,94. Setelah dilakukan intervensi pemberian aromaterapi minyak atsiri bunga mawar rata-rata skala nyeri persalinan menjadi 3,91 dengan standar deviasi 2,32. Terlihat nilai rata-rata perbedaan antara sebelum dan sesudah intervensi adalah 0,86 dengan standar deviasi 0,38 . Hasil uji statistic didapatkan nilai $\mathrm{P}=0,02$ hal ini berarti menunjukkan nilai $\mathrm{p}<0,05$ yang artinya maka dapat disimpulkan berdasarkan instrument skala nyeri Wong Baker Faces Pain Rating Scale (WBS) terdapat pengaruh aromaterapi minyak atsiri bunga mawar terhadap penurunan intensitas nyeri persalinan kala I fase aktif.

Tabel 3. Analisis Korelasi Skala Nyeri Persalinan Sebelum dan Sesudah diberikan Intervensi

\begin{tabular}{cccc}
\hline \multicolumn{2}{c}{ Variabel } & n & Correlation Coefficient \\
\hline Numeric Rating Scale (NRS) & 44 & 0,65 \\
$\begin{array}{l}\text { Wong Baker Faces Pain } \\
\text { Scale (WBS) }\end{array}$ & 44 & 0,51 \\
\hline
\end{tabular}

*Spearman Rho

Pengaruh aromaterapi minyak atsiri bunga mawar terhadap penurunan intensitas nyeri persalinan kala I fase aktif berdasarkan skala nyeri persalinan Numeric Rating Scale (NRS) menunjukkan Correlation Coefficient sebesar 0.65, maka nilai ini menandakan 
pengaruh yang kuat. Sedangkan Correlation Coefficient pada skala nyeri persalinan berdasarkan Wong Baker Faces Pain Rating Scale (WBS) menunjukkan angka 0.51, nilai ini menandakan pengaruh yang sedang.

\section{Tingkatan Nyeri Persalinan Kala I Fase Aktif pada Ibu Bersalin Sebelum Diberikan Aromaterapi Minyak Atsiri Bunga Mawar}

Nilai rata-rata skala nyeri persalinan antara sebelum diberikan aromaterapi minyak atsiri bunga mawar berdasarkan instrument Numeric Rating Scale (NRS) adalah 5,43. Standar deviasi menunjukkan angka 1,52 dan standar eror 0,23. Sedangkan berdasarkan instrumen Wong Baker Faces Pain Rating Scale (WBS) rata-rata intensitas nyeri persalinan sebelum diberikan aromaterapi minyak atsiri bunga mawar adalah 4,77 dengan standar deviasi 1,939 dan standar eror 0,292.

Nyeri persalinan ini disebabkan adanya regangan segmen bawah rahim. (Farrer H, 2001) Intensitas nyeri sebanding dengan kekuatan kontraksi dan tekanan yang terjadi, nyeri bertambah ketika mulut rahim dalam dilatasi penuh akibat tekanan bayi terhadap struktur panggul diikuti regangan dan perobekan jalan lahir. Efek yang ditimbulkan oleh nyeri persalinan salah satunya adalah efek psikologis seperti kecemasan dan stress dimana jika ibu bersalin tidak mampu mengatasi kecemasan yang dialaminya maka nyeri yang dirasakan juga bertambah.

Usia merupakan faktor penting yang mempengaruhi nyeri, perbedaan perkembangan, yang ditemukan diantara kelompok usia remaja dan dewasa dapat mempengaruhi bagaimana anak-anak dan lansia bereaksi terhadap nyeri. Berdasarkan tabel 5.1 sebesar $14 \%$ ibu bersalin berusia $<20$ tahun hal ini menunjukkan masih adanya ibu bersalin dibawah usia ideal. Sedangkan usia ideal untuk melahirkan dan mengakhiri kehamilan adalah diantara 20-35 tahun. (Saputra D., 2016) Jumlah persalinan juga mempengaruhi nyeri persalinan pada tabel 5.4 menunjukan sebagian besar atau $75 \%$ ibu bersalin pada hamil kedua atau

multigravida dan hanya terdapat $25 \%$ ibu bersalin yang merupakan primigravida. Hal ini menunjukkan bahwa pengalaman nyeri sebelumnya berpengaruh karena ibu bersalin yang pernah merasakan rasa nyeri yang sama akan mampu mengendalikan dirinya sehingga akan dapat beradaptasi dengan nyeri yang dirasakan. 


\section{Tingkatan Nyeri Persalinan Kala I Fase Aktif pada Ibu Bersalin Sesudah Diberikan Aromaterapi Minyak Atsiri Bunga Mawar}

Rata-rata intensitas nyeri persalinan berdasarkan instrument Numeric Rating Scale (NRS) sesudah diberikan aromaterapi minyak atsiri bunga mawar adalah 4,50 dengan standar deviasi 1,85 dan standar eror 0,28. Sedangkan berdasarkan instrumen Wong Baker Faces Pain Rating Scale (WBS) rata-rata intensitas nyeri persalinan sesudah diberikan aromaterapi minyak atsiri bunga mawar adalah 3,91 dengan standar deviasi 2,32 dan standar eror 0,35 . Klien yang merasa nyeri akan berusaha untuk menghilangkan rasa nyeri itu agar ketidaknyamanan yang dirasakan hilang. Dalam melakukan intervensi kebidanan, manajemen nonfarmakologi merupakan tindakan dalam mengatasi respon nyeri klien. (Andarmoyo, S. dkk. 2013).

Bunga mawar bersifat anti depresan sehinggan dapat membuat jiwa menjadi tenang. Hal ini sesuai dengan penelitian Utami R. \& Nurul M., 2013) bahwa metode paling efektif untuk mengurangi intensitas nyeri kala 1 fase aktif persalinan normal primigravida adalah dengan memberikan dua puluh menit aromaterapi rose effleurage. Aromaterapi minyak atsiri bunga mawar merupakan salah satu metode yang bisa digunakan untuk mengurangi penyebab dari rasa nyeri. Aroma yang berasal dari aromaterapi bekerja mempengaruhi emosi seseorang dengan limbic (lewat sistem olfaktori) dan pusat emosi otak. Bau yang berasal dari aromaterapi diterimah oleh reseptor dihidung kemudian dikirimkan ke bagian medulla spinalis di otak, didalam hal ini kemudian akan meningkatkan gelombanggelombang alfa diotak dan gelombang-gelombang alfa inilah yang membantu untuk merasa relaksasi.

\section{Pengaruh Aromaterapi Minyak Atsiri Bunga Mawar terhadap Penurunan Intensitas Nyeri Persalinan Kala 1 Fase Aktif}

Rata-rata skala nyeri persalinan berdasarkan Numeric Rating Scale (NRS) sebelum intervensi adalah 5,43 dengan standar deviasi 1,516. Setelah dilakukan intervensi pemberian aromaterapi minyak atsiri bunga mawar rata-rata skala nyeri persalinan menjadi 4,50 dengan standar deviasi 1,85. Terlihat nilai rata-rata perbedaan antara sebelum dan sesudah intervensi adalah 0,93 dengan standar deviasi 0,33.

Hasil uji statistik didapatkan nilai $\mathrm{P}=0,0001$ dengan taraf signifikan nilai $\mathrm{p}<0,05$, maka dapat disimpulkan berdasarkan instrument skala nyeri Numeric Rating Scale (NRS) 
terdapat pengaruh aromaterapi minyak atsiri bunga mawar terhadap penurunan intensitas nyeri persalinan kala I fase aktif.

Diketahui rata-rata skala nyeri persalinan berdasarkan Wong Baker Faces Pain Rating Scale (WBS) sebelum intervensi adalah 4,77 dengan standar deviasi 1,94. Setelah dilakukan intervensi pemberian aromaterapi minyak atsiri bunga mawar rata-rata skala nyeri persalinan menjadi 3,91 dengan standar deviasi 2,32. Terlihat nilai rata-rata perbedaan antara sebelum dan sesudah intervensi adalah 0,86 dengan standar deviasi 0,38. Hasil uji statistic didapatkan nilai $\mathrm{P}=0,02$ dengan taraf signifikan nilai $\mathrm{p}<0,05$, maka dapat disimpulkan berdasarkan instrument skala nyeri Wong Baker Faces Pain Rating Scale (WBS) terdapat pengaruh aromaterapi minyak atsiri bunga mawar terhadap penurunan intensitas nyeri persalinan kala I fase aktif.

Minyak atsiri bunga mawar yang digunakan melalui inhalasi dapat bermanfaat meningkatkan kewaspadaan, meningkatkan daya ingat, meningkatkan kecepatan dalam berhitung serta melegakan otot dan pikiran. ${ }^{13}$ Bunga mawar berkhasiat sebagai cell rejuvenator yang membuat sel muda kembali, antiseptic, dan anti radang. Baunya merupakan anti depresan, sedative dan meringankan stress. (Wahyuni S. 2012).

Pemberian aromaterapi pada ibu bersalin mampu mengeluarkan neuromodulator yaitu endorphin dan enkafalin yang berfungsi sebagai penghilang rasa sakit alami dan menghasilkan perasaan tenang sehingga dapat mempengaruhi intensitas nyeri persalinan. (Karlina S. dkk, 2014).

Penelitian Pratiwi R. dkk. (2012) menyimpulkan bahwa ada pengaruh latihan teknik pernafasan menggunakan aromaterapi lavender terhadap intensitas skala nyeri dan berkurangnya nyeri pada ibu post section caesarea. Senada dengan pernyataan tersebut penelitian Utami R. \& Nurul M. (2013) telah membuktikan bahwa metode paling efektif untuk mengurangi intensitas nyeri kala I fase aktif persalinan normal primigravida adalah dengan memberikan dua puluh menit aromaterapi rose effleurage.

Hasil penelitian juga menunjukan terdapat enam responden dengan skala nyeri tetap setelah diberikan aromaterapi minyak atsiri bunga mawar. Menurut data yang peneliti dapatkan semua responden menyukai wangi aromaterapi minyak atsiri bunga mawar. Walaupun semua responden menyukai wangi aromaterapi bunga mawar, ada 6 responden dengan skala nyeri tetap. Hal ini terjadi dikarenakan perbedaan karakteristik nyeri. Lima 
dari enam responden dengan skala nyeri tetap adalah ibu primigravida atau ibu yang baru pertama kali melahirkan. Nyeri dipengaruhi oleh pengalaman masa lalu, sedangkan seorang ibu primi gravida tidak mempunyai pengalaman melahirkan sebelumnya. Seringkali individu yang lebih berpengalaman dengan nyeri yang dialaminya, makin takut individu tersebut terhadap peristiwa menyakitkan yang akan diakibatkan. Individu ini mungkin akan lebih sedikit mentoleransi nyeri, akibatnya ia ingin nyerinya segera reda sebelum nyeri tersebut menjadi lebih parah. (Bare B. \& Smeltzer S., 2001) Maka dari itu karakteristik responden seorang primigravida cenderung memiliki skala nyeri yang tetap dibandingkan dengan ibu multigravida.

Persalinan kala I fase aktif berdasarkan skala nyeri persalinan Numeric Rating Scale (NRS) menunjukkan Correlation Coefficient sebesar 0.65, maka nilai ini menandakan pengaruh yang tinggi. Sedangkan Correlation Coefficient pada skala nyeri persalinan berdasarkan Wong Baker Faces Pain Rating Scale (WBS) menunjukkan angka 0.51, nilai ini menandakan pengaruh yang rendah. Perbedaan angka Correlation Coefficient menandakan bahwa pengaruh aromaterapi minyak atsiri bunga mawar terhadap intensitas nyeri persalinan kala 1 fase aktif lebih dirasakan oleh ibu bersalin dibandingkan dengan yang dilihat oleh bidan.

\section{SIMPULAN}

Terdapat pengaruh aromaterapi minyak atsiri bunga mawar terhadap penurunan intensitas nyeri persalinan kala 1 fase aktif ditandai dengan penurunan rata-rata intensitas nyeri sebelum dan sesudah diberikan aromaterapi minyak atsiri bunga mawar. Intensitas nyeri persalinan kala 1 fase aktif sebelum diberikan aromaterapi minyak atsiri bunga mawar berdasarkan Numeric Rating Scale sebesar 5,43 dan berdasarkan Wong Baker Faces Pain Rating Scale sebesar 4,77. Intensitas nyeri persalinan kala 1 fase aktif sesudah diberikan aromaterapi minyak atsiri bunga mawar berdasarkan Numeric Rating Scale sebesar 4,5 dan berdasarkan Wong Baker Faces Pain Rating Scale sebesar 3,91. Terdapat penurunan rata-rata intensitas nyeri sebelum dan sesudah diberikan aromaterapi minyak atsiri bunga mawar berdasarkan Numeric Rating Scale yaitu sebesar 0,93 dan berdasarkan Wong Baker Faces Pain Rating Scale sebesar 0,86. Rekomendasi bagi Institusi Pendidikan yaitu penambahan buku mengenai terapi komplementer penggunaan aromaterapi bagi ibu 
bersalin yang diintegrasikan dalam kurikulum Pendidikan Kebidanan. Sedangkan bagi Profesi Bidan untuk mengadakan pelatihan dan Midwifery Update mengenai pengembangan asuhan kebidanan khususnya pemberian aromaterapi minyak atsiri bunga mawar dalam menurunkan nyeri persalinan. Rekomendasi untuk Fasilitas Pelayanan Kesehatan agar pemberian aromaterapi minyak atsiri bunga mawar merupakan salah satu alternative yang dapat digunakan sebagai bahan pertimbangan untuk memodifikasi mengatasi nyeri persalinan di Fasilitas Pelayanan Kesehatan.

\section{REFERENSI}

1. Andarmoyo S, Sulistyo, Suharti. 2013. Persalinan Tanpa Nyeri Berlebihan. Yogyakarta: Ar-Ruzz.

2. Bare B, Smeltzer S. 2001. Buku Ajar Keperawatan Medikal Bedah. Jakarta: EGC.

3. Balkam J. 2001.Aromaterapi. Bandung: Effhar Offset; 401 p.

4. Farrer H. 2001. Perawatan Maternitas. 2nd ed. Jakarta: EGC.

5. IASP. 2015. What is Neuropathic Pain. In 2015. p.

6. Jones, Nelson R. 2006.Teori dan Praktek Konseling dan Terapi (Terjemahan Helly Prayitno dan Sri Mulyantini). Yogyakarta: Pustaka Pelajar.

7. Karlina S, Reksohusodo S, Widayati A. 2014. The Influence of Lavender Aromatherapy Inhalation to Relieve Physiological Labor Pain Intensity in Primipara Inpartu Active Phase in BPM "Fetty Fathiyah" Mataram City. Fak Kedokt Univ Brawijaya.;108-19.

8. Kemenkes RI. 2008. Asuhan Persalinan Normal. Jakarta: JNPK-KR.

9. Koensoemardiyah. 2009. A-Z Aromaterapi untuk Kesehatan, Kebugaran dan Kecantikan. Yogyakarta: Lily Publisher.

10. Llewllyn D. 2001. Dasar-dasar Obstetri \& Ginekologi. 66th ed. Jakarta: Hipokratis.

11. Mander R. 2004. Nyeri Persalinan. Jakarta: Penerbit Buku Kedokteran EGC.

12. Notoatmodjo S. 2005. Metodologi Penelitian Kesehatan. Jakarta: Rineka Cipta.

13. Pemerintah Republik Indonesia. 2014. Peraturan Pemerintah Republik Indonesia Nomor 103 Tentang Pelayanan Kesehatan Tradisional. In Jakarta.

14. Poerwadi R. 2006. Aromaterapi Sahabat Calon Ibu. Jakarta: Dian Rakyat.

15. Pratiwi R, Ermiati, Widiasih R. Penurunan Intensitas Nyeri Akibat Luka Post Sectio Caesarea Setelah Dilakukan Latihan Teknik Relaksasi Pernapasan Menggunakan 
Aromaterapi Lavender di Rumah Sakit Al Islam Bandung. Univ Padjajaran. 2012;115.

16. Price S, Price L. 1997. Aromaterapi bagi Profesi Kesehatan. Jakarta: EGC.

17. Ratnaningsih. 2010. Perbedaan Tingkat Nyeri pada Ibu Bersalin. Jakarta: EGC.

18. Saputra D. 2016. Meraih Jendela Kesempatan Melalui Program Keluarga Berencana Nasional.

19. Sharma S. 2009. Aromaterapi. Tangerang: Karisma.

20. Sujiyatini. 2011. Asuhan Kebidanan II (Persalinan). Yogyakarta: Rohiro Press;. 24 p.

21. Sumarah. 2009. Perawatan Ibu Bersalin (Asuhan Kebidanan Pada Ibu Bersalin). Yogyakarta: Fitramaya.

22. Tamsuri. 2007. Konsep dan Penatalaksanaan Nyeri. Jakarta: EGC.

23. Tournaire M, Theau-yonneau A. 2007. Complementary and Alternative Approaches to Pain Relief During Labor.;4(March):409-17.

24. Turlina L, Fadhilah N. 2017. Pengaruh Pemberian Aromaterapi Lavender terhadap Penurunan Tingkat Nyeri pada Ibu Bersalin Kala I Fase Aktif di BPM Ny. Margelina, Amd. Keb Desa Supenuh Kecamatan Sugio Kabupaten Lamongan. STIKES Muhammadiyah Lamongan. Vol. 09(01):23-8.

25. Utami R, Nurul M. 2013. Perbedaan Efektivitas Lama Pemberian Rose Effleurage Terhadap Intensitas Nyeri Kala I Fase Aktif pada Persalinan Normal Primigravida di Kota Semarang Tahun 2013. Kebidanan.;2(4).

26. Wahyuni S. 2012. Pengaruh Pemberian Aromaterapi Minyak Atsiri Bunga Mawar terhadap Tingkat Stress Mahasiswa dalam Mengikuti Pembelajaran Klinik di PSIK FK UNAND Tahap Profesi Tahun 2012. Univ Andalas. 